\title{
PERLINDUNGAN HUKUM TERHADAP PIHAK KETIGA SEBAGAI PEMILIK ALAT BERAT YANG DIGUNAKAN DALAM MELAKUKAN TINDAK PIDANA PERAMBAHAN HUTAN
}

\author{
Erlita Sipayung*, Kartina Pakpahan, Heni Widiyani, dan Nelly Sri Devi \\ Universitas Prima Indonesia \\ Jalan Sekip Simpang Sikambing, Medan, Sumatera Utara \\ 3rlita.sipayung@gmail.com
}

\begin{abstract}
Forests are the lungs of the earth that produce huge amounts of oxygen that humans need to live. But at this time there are many criminal acts of forest encroachment that are carried out irresponsibly, so that it harms many parties such as third parties as owners of heavy equipment used to commit acts of forest encroachment. Article 78 paragraph (15) of Law Number 41 of 1999 concerning Forestry which stipulates that all forest products and proceeds of crime, violations or transportation equipment used to commit crimes or violations will be confiscated for the State. From this article, injustice arises for third parties who have heavy equipment when renting to others because their heavy equipment is seized by the State. Because the third party only rents the heavy equipment to other people without knowing that the person who hired uses it for a crime. This study uses a normative juridical method with library research data collection techniques, qualitative data analysis using inductive deductive methods. The legal action that can be taken by a third party is to object to the seizure placed on the object or object belonging to a third party as long as the case against it has not yet had a decision that has permanent legal force. By taking legal action against third parties to recover their property that was confiscated based on a decision concerning evidence of a crime which was considered relevant enough to provide justice to a third party.
\end{abstract}

Keywords: Legal Protection, Heavy Equipment, Criminal Acts of Forest Encroachment

\begin{abstract}
Abstrak
Hutan adalah sebagai paru-paru bumi yang menghasilkan oksigen dalam jumlah yang sangat besar yang dibutuhkan manusia untuk hidup. Namun pada saat ini banyak terjadi tindak pidana perambahan hutan yang dilakukan dengan tidak bertanggung jawab, sehingga merugikan banyak pihak seperti pihak ketiga selaku pemilik alat berat yang digunakan untuk melakukan tindak pidana perambahan hutan. Pasal 78 ayat (15) Undang-undang Nomor 41 tahun 1999 tentang Kehutanan yang mengatur bahwa semua hasil hutan dan hasil kejahatan, pelanggaran atau alat-alat angkutan yang digunakan untuk melakukan kejahatan ataupun pelanggaran maka akan dirampas untuk Negara. Dari pasal ini timbul ketidakadilan bagi pihak ketiga yang memiliki alat berat ketika menyewakan kepada orang lain oleh sebab alat beratnya dirampas oleh Negara. Oleh karena pihak ketiga hanya menyewakan alat beratnya kepada orang lain tanpa mengetahui orang yang menyewa menggunakannya untuk tindak pidana. Penelitian ini mengunakan metode yuridis normatif dengan teknik pengumpulan data penelitian kepustakaan, analisis data secara kualitatif menggunakan metode deduktif induktif. Upaya hukum yang dapat dilakukan oleh pihak ketiga adalah mengajukan keberatan atas penyitaan yang diletakan terhadap objek atau benda milik pihak ketiga selama perkara yang dilawan belum mempunyai putusan yang berkekuatan hukum tetap. Dengan melakukan upaya hukum perlawanan pihak ketiga untuk memperoleh kembali barang miliknya yang dirampas berdasarkan putusan yang menyangkut barang bukti tindak pidana yang dinilai cukup relevan sehingga memberikan keadilan pada pihak ketiga.
\end{abstract}

Kata Kunci: Perlindungan Hukum, Alat Berat, Tindak Pidana Perambahan Hutan 


\section{Pendahuluan}

Hutan merupakan karunia Tuhan Yang Maha Esa yang dianugerahkan kepada manusia sebagai kekayaan alam yang tidak ternilai harganya dan wajib disyukuri. Hutan mempunyai peranan yang penting bagi kemakmuran dan kesejahteraan rakyat Indonesia, secara nyata hutan bermanfaat untuk menghasilkan kayu dan juga sebagai salah satu penentu sistem penyangga kehidupan penyerasi dan penyeimbang lingkungan. Melalui Undang-undang Nomor 41 tahun 1999 tentang kehutanan, bahwa Negara memiliki wewenang kepada pemerintah untuk :

a. Mengatur dan mengurus segala sesuatu yang berkaitan dengan hutan kawasan hutan dan hasil hutan.

b. Menetapkan status wilayah tertentu sebagai kawasan hutan atau kawasan hutan sebagai bukan kawasan hutan.

Berdasarkan Undang-undang Nomor 41 Tahun 1999 tentang kehutanan Pasal 6 ayat (2) yang menyatakan bahwa pemerintah menetapkan hutan berdasarkan fungsi pokok kawasan hutan terdiri dari antara lain sebagai berikut hutan konservasi, hutan lindung dan hutan produksi. Pemerintah memberikan Izin Usaha pemanfaatan kawasan diatur dalam Pasal 26 Undang-undang Nomor 41 tahun 1999, bahwa salah satu izin dalam rangka pemanfaatan hutan lindung berupa izin usaha pemanfaatan kawasan, selanjutnya disingkat IUPK. Pemanfaatan kawasan pada hutan lindung dilakukan, antara lain melalui kegiatan usaha budidaya tanaman obat, budidaya tanaman hias, budidaya jamur, budidaya lebah, penangkaran satwa liar, rehabilitasi satwa.
Dengan demikian Negara mengatur dan menetapkan hal-hal yang berkaitan dengan ruang lingkup kehutanan. Negara mengatur dan menetapkan hal-hal yang berkaitan dengan ruang lingkup kehutanan memperhatikan hak masyarakat hukum adat sepanjang kenyataannya masih ada dan diakui keberadaannya dan tidak bertentangan dengan kepentingan nasional. ${ }^{1}$ Kemajuan teknologi, memungkinkan masyarakat secara langsung maupun tidak langsung dapat merusak hutan tanpa memperdulikan dampak-dampak yang akan terjadi, seperti berkurangnya luas hutan, bencana alam, kerugian ekonomi.

Tidak jarang pemanfaatan hutan disalahgunakan oleh beberapa orang maupun dalam bentuk korporasi, perbuatan tersebut menyebabkan kerusakan hutan. Pohon-pohon ditebang tanpa ijin mengakibatkan berkurangnya luas hutan, terjadinya bencana alam. Orang perseorangan atau korporasi melakukan perambahan hutan dengan cara di tebang, maupun dengan alat-alat berat yang disewa melalui perorangan atau badan hukum. dan bagaimana jika alat-alat yang sudah disewa disalahgunakan untuk melakukan tindak pidana perambahan hutan oleh penyewa. Dengan demikian hal tersebutlah yang melatarbelakangi penelitian ini dengan judul "perlindungan hukum terhadap pihak ketiga sebagai pemilik alat berat dipakai melakukan tindak pidana perambahan hutan" Penelitian ini bertujuan untuk mengetahui bagaimana perlindungan hukum terhadap pihak ketiga sebagai pemilik alat berat dipakai melakukan tindak pidana perambahan hutan dan Bagaimana hukuman yang diberikan kepada pelaku tindak pidana perambahan hutan.

Ahmad Redi, Hukum Sumber Daya Alam Dalam Sektor Kehutanan. Jakarta: Sinar Grafika, 2014, hlm.3. 


\section{Pembahasan}

2.1. Perlindungan Hukum Terhadap Pihak Ketiga Sebagai Pemilik Alat Berat Dipakai Melakukan Tindak Pidana Perambahan Hutan.

Perlindungan hukum adalah memberikan pengayoman kepada hak asasi manusia yang dirugikan orang lain dan perlindungan tersebut diberikan kepada masyarakat agar mereka dapat menikmati semua hak-hak yang diterikan hukum. Menurut Soetjipto Rahardjo perlindungan hukum adalah upaya untuk melindungi kepentingan seseorang dengan cara mengalokasikan suatu kekuasaan untuk bertindak dalam kepentinganya dan merupakan tujuan hukum memberikan perlindungan kepada masyarakat. ${ }^{2}$ Perlindungan hukum melindungi subyek-subyek hukum melalui peraturan perundang-undangan yang berlaku dan dipaksakan pelaksanaannya dengan suatu sanksi. ${ }^{3}$

Setiap perusahaan dalam menjalankan perusahaannya harus mematuhi peraturan perundang-undangan. Jenis-jenis perusahaan di Indonesia yaitu usaha perseorangan maupun dalam bentuk intitusi. Perusahaan yang berbentuk badan hukum meliputi Perseroan Terbatas yang meliputi: ${ }^{4}$

a. Maskapai andil Indonesia (indonesische maatschappij op aandelen)

I.M.A didirikan sebagai kedudukan hukum dan memberikan kesempatan bagi orangorang bumi putra untuk mendirikan badanbadan hukum pada umumnya berlaku hukum adat tempat kedudukan I.M.A. b. Perseroan terbatas (PT)

Suatu badan hukum menjalankan usaha memiliki modal terdiri dari saham-saham. ${ }^{5}$

c. Koperasi

Koperasi adalah suatu perkumpulan orang bersifat terbatas, yang secara sukarela bergabung bersama untuk mencapai kesejahteraan ekonomi anggotanya dan berbentuk organisasi bisnis yang dikontrol secara demokratis, menerima pembagian yang adil atas untung rugi dari usaha. ${ }^{6}$

d. Badan usaha milik Negara (BUMN)

Badan usaha yang seluruh atau sebagian besar modalnya dimiliki oleh negara melalui penyertaan secara langsung yang berasal dari kekayaan negara yang dipisahkan. ${ }^{7}$

Salah satu bentuk bidang usaha yang dapat dijalankan oleh Perusahaan perseorangan maupun berbentuk Badan Hukum adalah menyewakan alat berat. Alat berat merupakan mesin berukuran besar yang didesain untuk melaksanakan fungsi konstruksi seperti pengerjaan tanah dan memindahkan bahan bangunan dan dapat digunakan di lahan perkebunan. Alat-alat berat dapat digunakan untuk membuka lahan perkebunan, yang biasanya digunakan untuk membuka lahan yaitu: ${ }^{8}$

\section{a. Bulldozer}

Bulldozer digunakan sebagai alat pendorong tanah lurus kedepan maupun kesamping, tergantung pada sumbu kendaraannya. Jenis Bulldozer yakni menggunakan roda

\footnotetext{
Soetjipto Rahardjo, Permasalahan Hukum di Indonesia. Bandung, 1983, hlm.38.

Muchsin, Perlindungan dan Kepastian Hukum, Surakarta, 2004, hlm.14.

Mulhadi, Diktat Hukum Perusahaan Bentuk-Bentuk Badan Usaha Diindonesia, Medan, 2016, hlm. 25-26.

Pasal 1 ayat 1 Undang-Undang Republik Indonesia Nomor 40 Tahun 2007 tentang Perseroan Terbatas.

Pasal 1 ayat 1 Undang-Undang Republik Indonesia Nomor 17 Tahun 2012 tentang Koperasi.

Pasal 1 ayat 1 Undang-Undang Republik Indonesia Nomor 17 Tahun 2012 tentang Koperasi.

Rochmanhadi, Alat-Alat Berat Dan Penggunaannya. Jakrta: Dunia Grafika Indonesia, 1992, hlm. 20.
} 
kelabang dan bulldozer yang menggunakan roda karet.

\section{b. Excavator}

Sebagai alat penggali tanah dan dapat juga digunakan sebagai alat pengangkut material kedalam truck namun sayangnya tidak dapat digunakan dalam jarak jauh.

Dalam menjalankan usaha pemilik alat berat perusahaannya dapat berbentuk perseroan terbatas. Perseroan Terbatas adalah badan hukum yang merupakan persekutuan modal, didirikan berdasarkan perjanjian, melakukan kegiatan usaha dengan modal dasar seluruhnya terbagi dalam saham dan memenuhi persyaratan peraturan perundang-undang. ${ }^{9}$ Tujuan perusahaan dalam menjalankan usahanya bertujuan memperoleh keuntungan dan laba. Perusahaan yang menyewakan alat berat memiliki kewajiban bertindak hati-hati untuk menyewakan alat berat kepada pihak lain (konsumen). Harga suatu alat berat tergolong mahal, maka perusahaan dalam mengadakan perjanjian dalam sewa-menyewa alat berat wajib bertindak hati-hati untuk mnghindari terjadinya masalah dengan pihak lain. Pengertian perjanjian sewa-menyewa pada Pasal 1548 KUHPerdata adalah suatu persetujuan dengan mana pihak yang satu mengikatkan dirinya untuk memberikan kenikmatan suatu barang kepada pihak lain selama waktu tertentu, dengan pembayaran suatu harga yang disanggupi oleh pihak yang terakhir itu. ${ }^{10}$ Pihak yang menyewakan adalah orang atau badan hukum yang menyewakan barang atau benda kepada pihak penyewa. Yang menjadi objek dalam perjanjian sewa-menyewa adalah barang dan harga dengan syarat barang yang disewakan adalah barang yang halal artinya tidak bertentangan dengan undangundang.

Oleh karena itu mengingat begitu kuatnya kekuatan mengikat suatu perjanjian maka tidak sembarangan membuat perjanjian ada syarat-syarat yang harus dipenuhi agar perjanjian menjadi sah dan mengikat para pihak. Syarat-syarat tersebut dikenal dengan syarat sahnya perjanjian sebagaimana diatur dalam Pasal 1320 KUHP perdata yaitu diperlukan 4 syarat yaitu: sepakat mereka yang mengikatkan dirinya, kecakapan untuk membuat suatu perikatan, suatu hal tertentu, dan suatu sebab yang halal.

Dalam perjanjian sewa-menyewa barang itu berada pada pihak penyewa. Persoalannya bagaimana jika pihak ketiga tidak mengetahui alat berat yang disewakan digunakan untuk melakukan tindak pidana, apakah pihak ketiga sebagai orang yang menyewakan alat berat dapat dipidana? Terhadap hal ini pihak ketiga sebagai orang yang menyewakan tidak dapat dipidana berdasarkan Pasal 197 ayat (1) huruf d KUHAP mengenai ketentuan pertimbangan hakim yang menyatakan pertimbangan disusun secara ringkas mengenai fakta dan keadaan beserta alat pembuktian yang diperoleh dari pemeriksaan disidang yang menjadi dasar penentuan-penentuan. Hal ini dijelaskan pula dalam Pasal 183 KUHAP yang menyatakan bahwa hakim tidak boleh menjatuhkan pidana kepada seorang kecuali apabila dengan sekurangkurangnya dua alat bukti yang sah. ia memperoleh keyakinan bahwa suatu tindak pidana benar-benar terjadi. Selain itu dalam hal ini pihak ketiga sebagai yang menyewakan juga ikut dirugikan. Adapun hak dan kewajiban pihak yang menyewakan dan

\footnotetext{
9 Pasal 1 angka 1 Undang-Undang Republik Indonesia Nomor 40 tahun 2007 tentang Perseroan Terbatas.

10 Salim, Hukum Kontrak Teori Dan Teknik Penyusunan Kontrak, Jakarta: Sinar grafika, 2003, hlm. 58.
} 
penyewa yaitu ${ }^{11}$ Hak dari pihak yang menyewakan adalah menerima harga sewa yang telah ditentukan, sedangkan kewajiban pihak yang menyewakan ialah menyerahkan barang yang disewakan kepada si penyewa, memelihara barang yang disewakan, memberikan hak kepada penyewa untuk menikmati barang yang disewakan, melakukan pembetulan pada waktu yang sama dan menanggung cacat dari barang yang disewakan.

Hak dari pihak penyewa adalah menerima barang yang disewakan dalam keadaan baik, kewajibannya adalah memakai barang sewa sebagai seorang kepala rumah tangga yang baik, artinya kewajiban memakainya seakan-akan kepunyaanya sendiri. dan Membayar harga sewa pada waktu yang telah ditentukan. Pada Pasal 1553 KUH Perdata mengatur tentang resiko atas musnahnya barang menyatakan bahwa musnahnya suatu barang objek sewa dapat dibagi menjadi dua macam yaitu musnah secara total dan musnah sebagia dari objek sewa. Jika barang yang disewakan itu musnah secara keseluruhan diluar kesalahan pada masa sewa, perjanjian sewa-menyewa pun gugur demi hukum dan resiko ditanggung oleh pihak yang menyewakan. Jika barang yang disewakan hanya sebagian yang musnah maka penyewa dapat meminta pengurangan harga sewa atau meminta pembatalan perjanjian sewa-menyewa. ${ }^{12}$

Setiap perjanjian harus benar-benar dilaksanakan kalau tidak, maka akan dikategorikan sebagai perbuatan wanprestasi atau ingkar janji yang memberikan hak kepada pihak yang dirugikan untuk menuntut ganti rugi. Kepada pihak yang dirugikan dapat menuntut ganti rugi sebagai mana dalam Pasal 1635 KUH perdata. Setiap perbuatan melawan hukum yang membawa kerugian kepada orang lain, mewajibkan orang karena salahnya menerbitkan kerugian itu, mengganti kerugian tersebut. Karena hal itu sepenuhnya adalah kesalahan dari si penyewa yang telah menyalahgunakan alat berat yang disewakan untuk melakukan tindak pidana.

Bagaimana penyelesaian jika alat berat milik pihak ketiga disita oleh Negara, hal apa yang dapat dilakukan pihak ketiga? Maka yang dapat dilakukan pihak ketiga sebagai pihak yang menyewakan objek ataupun benda kepada si penyewa berhak melakukan upaya perlawanan selaku pihak ketiga (derden verzet) yang mengajukan keberatan atas penyitaan yang diletakan terhadap objek atau benda milik pihak ketiga yang diatur dalam ketentuan Pasal 206, Pasal 227-228 R.Bg dan Pasal 195 ayat (6) HIR. Maka dari itu derden verzet dapat diajukan pemilik selama perkara yang dilawan belum mempunyai putusan yang berkekuatan hukum tetap.

Bentuk perlindungan terhadap hak yang menyewakan, hukum memegang peranan untuk mengembalikan hak yang menyewakan dari kepentingan lain. Adapun kaitannya dengan upaya hukum perlawanan pihak ketiga karena adanya sarana perlindungan hukum preventif, artinya pemberian kesempatan untuk mengajukan keberatan atas putusan pengadilan, dan merupakan saranan perlindungan hukum represif, artinya pemberian perlindungan yang bertujuan untuk menyelesaiakan sengketa. Penggunaan upaya hukum perlawanan pihak ketiga (derden verzet) dipandang sebagai bentuk perlindungan hukum bagi pihak ketiga untuk memperoleh kembali barang 
miliknya yang dirampas berdasarkan putusan yang menyangkut barang bukti tindak pidana yang dinilai cukup relevan.

\subsection{Hukuman Kepada Pelaku yang Melakukan Tindak Pidana Perambahan Hutan.}

Tindak pidana adalah perbuatan seseorang atau sekelompok orang yang menimbulkan peristiwa pidana atau perbuatan melanggar hukum pidana dan diancam dengan hukuman. Tindak pidana dapat juga diartikan suatu kejadian yang mengandung unsur-unsur perbuatan yang dilarang oleh undangundang, sehingga siapa yang menimbulkan peristiwa itu dapat dikenai saksi pidana. ${ }^{13}$

Salah satunya adalah tindak pidana perambahan hutan di Indonesia yang telah lama terjadi sehingga menyebabkan kerusakan hutan. Banyak bentuk kejahatan yang dilakukan dibidang kehutanan yang dilakukan oleh perorangan maupun korporasi sehingga hukum positif belum pernah merumuskan tujuan pemidanaan selama ini wacana tentang tujuan pemidanaan tersebut masih dalam tataran yang bersifat teoritis. ${ }^{14}$ Namun sebagai bahan kajian rancangan kitab undang-undang hukum pidana (KUHP) nasional telah menetapkan tujuan pemidanaan pada buku kesatu ketentuan umum dalam Bab II dengan judul pemidanaan, pidana dan tindakan tujuan pemidanaan menurut Wirjono Prodjodikoro, yaitu: 15

a. menakut-nakuti orang jangan sampai melakukan kejahatan. Agar dikemudian hari tidak melakukan kejahatan lagi.

b. mendidik atau memperbaiki orang-orang yang melakukan kejahatan agar menjadi orang yang baik tabiatnya sehingga

bermanfaat bagi masyarakat.

Tindak kejahatan perambahan hutan juga tidak lepas dari perbuatan manusia yang melakukan perambahan hutan atau mengambil hasil hutan yang telah dilindungi oleh Negara. Tindak pidana kehutanan adalah "perbuatan melanggar ketentuan Undang-undang Nomor 41 Tahun 1999 tentang kehutanan yang telah diganti dengan Undangundang Nomor 18 Tahun 2013 tentang pencegahan dan pemberantasan perusakan hutan, (yang selanjutnya disingkat $\mathrm{P} 3 \mathrm{H}){ }^{16}$ Undang-undang kehutanan lama dianggap belum cukup memberikan landasan hukum bagi perkembangan pembangunan kehutanan dan Undang-undang kehutanan yang baru dihadirkan bukan untuk meluruskan kesalahan atau kekeliruan yang telah dilaksanakan oleh Undang-undang kehutanan lama. Undang-undang kehutanan yang lama dianggap tidak mampu lagi mengikuti perkembangan zaman sebagai landasan hukum bagi perkembangan pembangunan sektor kehutanan. Berdasarkan pertimbangan tersebut maka diatur ke dalam Undang-undang Nomor 18 Tahun 2013 tentang Pencegahan Dan Pemberantasan Perusakan Hutan (P3H). Dalam kebijakan formulasi hukum pidana pada Undangundang tersebut, jenis-jenis tindak pidana dan sistem pemidanaan mengatur ancaman pidana minimum khusus sampai dengan maksimum yang dibedakan pertanggungjawaban pidananya terhadap perseorangan, yang berada di sekitar atau dalam kawasan hutan, korporasi dan pejabat pemerintah.

13 J.b. Daliyo, Pengantar Hukum Indonesia, Jakarta: Prenhalindo, 2001, hlm. 93.

14 Abdul Muis dan Mohammad Taufik Makarao, Hukum Kehutanan di Indonesia. Jakarta: PT. Bineka cipta, hlm. 1.

15 Wirjono Prodjodikoro, Hukum Acara Pidana Di Indonesia. Bandung: Sumur Bandung, 1981, hlm. 16.

16 "Penyidikan Terhadap Tindak Pidana Perambahan Kawasan Hutan Cagar Biosfer Giam Siak Kecil Oleh Kepolisian Resrot Bengkalis Berdasarkan Undang-Undang Nomor 18 Tahun 2013" <https://www.dap laksmi, w edorita-mahasiswa (jom) bidang ilmu hukum,2018-jom.unri,ac.id> diakses tanggal 27 febuari 2019. 
Maka telah lahir Undang-undang yang baru Nomor 18 Tahun 2013 tentang pencegahan hutan dan pemberantasan hutan yang telah disahkan dan menggantikan Undang-undang yang lama Nomor 41 Tahun 1999, yang di harap kan mampu menjamin kepastian hukum dengan menitikberatkan pada pemberantasan perusakan hutan yang dilakukan secara terorganisasi. Adapun perbedaan dalam dalam ketentuan pidana di dalam Undang-Undang lama dan Undang-undang yang baru yaitu, Undangundang Nomor 18 Tahun 2013 ketentuan pidananya menentukan pertanggungjawaban individu yang sesuai dengan sikap tindak pelaku apakah sengaja atau karena kelalaian dan memiliki hukum berbeda, sedangkan Undang-undang Nomor 41 Tahun 1999 yang hanya menentukan sikap tindak pidananya berdasarkan sengaja dalam pertanggungjawabannya. Selain itu di dalam Undang-undang yang lama hanya mewajibkan kepada penanggungjawab perbuatan itu untuk membayar ganti rugi sesuai dengan kerusakan atau akibat yang telah di timbulkan kepada Negara. Undang-Undang yang baru tidak mampu menyeret pelaku kejahatan di bidang kehutanan terutama pejabat Negara, aparat penegak hukum, atau pegawai negeri yang terlibat melakukan kolusi karena tidak diatur secara khusus di dalam Undang-undang Nomor 41 Tahun 1999.17

Selain itu dalam Pasal 112 Undang-undang Nomor 18 Tahun 2013 menyatakan ketentuan Pasal 50 ayat 1 dan ayat 3 huruf a, huruf $f$, huruf $g$, huruf $j$, serta huruf $k$ selain itu ketentuan Pasal 78 ayat 1 mengenai ketentuan Pasal 78 ayat 1 mengenai ketentuan pidana terhadap Pasal 50 ayat 1 serta ayat 2 mengenai ketentuan pidana terhadap Pasal
50 ayat 3 huruf a dan huruf $b$, ayat 6 , ayat 7 , ayat 9 dan ayat 10 dinyatakan dicabut dan tidak berlaku lagi.

Seperti ketentuan pidana didalam pasal 78 yang melanggar ketentuan sebagaimana dimaksud dalam pasal 50 yaitu setiap orang di larang merusak prasaranan dan sarana perlindungan hutan, Setiap orang yang diberikan izin usaha pemamfaatan, jasa lingkungan, izin usaha pemanfaatan hasil hutan kayu dan bukan kayu dilarang melakukan kegiatan yang menimbulkan kerusakan hutan. ${ }^{18}$ Dan setiap orang dilarang merambah hutan, membakar hutan, menebang dan memanen tanpa izin, pertambangan hutan lindung, mengangkut dan menguasai hasil hutan tanpa surat keterangan hasil hutan, mengembalakan ternak dalam hutan, membawa alat-alat berat, membuang benda-benda yang dapat menyebabkan kebakaran, mengangkut tumbuhantumbuhan dan satwa liar dari kawasan hutan tanpa izin, dan bagi siapa yang melanggar ketentuan yang sudah ada maka akan di jatuhkan hukuman pidana penjara paling lama 10 Tahun dan denda paling banyak Rp 50.000.000.000_-.

Sedangkan di dalam Pasal 82 Undangundang Nomor 18 Tahun 2013 tentang pencegahan dan pemberantasan tindak pidana kehutanan memberikan sanksi, (1) barang siapa dengan sengaja melakukan penebangan pohon dalam kawasan hutan yang tidak sesuai dengan izin pemanfaatan hutan sebagaimana dalam Pasal 12 huruf a,b, c dipidana dengan pidana penjara paling singkat 1 (satu) tahun dan paling lama 5 (lima) tahun serta pidana denda paling sedikit Rp.500.000.000.00 (lima ratus juta rupiah) dan paling banyak Rp.2.500.000.000.00 (dua miliar lima ratus juta

17 "Kebijakan Hukum Pidana Dalam Menanggulangi Tindak Pidana lleggal Logging Di Provinsi Jambi" <https/l:S Abdullah-legalitas: jurnal hukum,2016-legalitas.unbari.ac.id> diakses tanggal 27 febuari 2019.

18 "Peranan Kebijakan Negara Terhadap Perlindungan Hutan Untuk Menekan Laju Deforestasi Taman Nasional Tesso Nilo" <https/l: L Ikhsan, S Abdullah-legalitas-jurnal hukum,2017-legalitas.Unbari.ac.id> diakes tanggal 27 febuari 2019. 
rupiah) dan hukuman bagi pelaku tindak pidana perambahan hutan yang dilakukan oleh perorangan dengan membawa alat-alat berat adalah berdasarkan pasal 85 Undang-undang Nomor 13 Tahun 2018 orang perseorangan yang dengan sengaja membawa alat-alat berat yang lazim atau patut diduga akan digunakan untuk mengangkut hasil hutan didalam kawasan hutan tanpa izin pejabat yang berwenang sebagaimana dimaksud dalam pasal 12 huruf $\mathrm{g}$ dipidana dengan pidana dengan pidana penjara paling singkat 2 (dua) tahun dan paling lama 10 (sepuluh) tahun dan pidana denda paling sedikit Rp2.000.000.000,00 (dua miliar rupiah) dan paling banyak Rp10.000.000.000,00 (sepuluh miliar rupiah).

Oleh itu kita sebagai generasi penerus diharapkan mau ikut serta dalam melestarikan hutan, ikut mencegahan perusakan hutan dan pemberantasan perusakan hutan di daerah kita berada. Sebagaimana tang telah diatur dalam Pasal 1 angka 3 Undang-undang Nomor 18 Tahun 2013 memberikan pengertian perusakan hutan sebagai proses, cara atau perbuatan merusak hutan melalui kegiatan pembalakan liar, pengunaan kawasan hutan tanpa izin atau penggunaan izin yang bertentangan dengan maksud dan tujuan pemberian izin di dalam kawasan hutan yang telah ditetapkan, yang telah ditunjuk, ataupun yang sedang di proses penetapannya oleh pemerintah.

Dalam rangka pencegahan perusakan hutan, pemerintah membuat kebijakan berupa:

1. Koordinasi lintas sektor dalam pencegahan dan pemberantasan perusakan hutan.

2. Pemenuhan kebutuhan sumber daya aparatur pengamanan hutan.
3. Insentif bagi para pihak yang berjasa dalam menjaga kelestarian hutan.

4. Peta penunjukan kawasan hutan atau koordinat geografis sebagai dasar yuridis batas kawasan hutan.

5. Pemenuhan kebutuhan sarana dan prasarana pencegahan dan pemberantasan perusakan hutan.

Pemberantasan perusakan hutan adalah segala upaya yang dilakukan untuk menindak secara hukum terhadap pelaku perusahaan hutan baik langsung, tidak langsung maupun yang terkait lainnya. Dalam pemberantasan perusakan hutan wajiban untuk melakukan pemberantasan pada pemerintahan dan pemerintah daerah. ${ }^{19}$ Pemberantasan perusakan hutan dilakukan dengan cara menindak secara hukum pelaku perusakan hutan, baik langsung, tidak langsung, maupun yang terkait lainnya. Tindakan secara hukum tersebut dilakukan melalui proses penyelidikan, penyidikan, penuntutan, dan pemeriksaan di sidang pengadilan sesuai dengan hukum acara pidana kecuali apabila Undang-Undang Nomor 18 Tahun 2013 menentukan lain.

Perkara perusakan hutan memiliki keistimewaan dalam proses penyelidikan, penyidikan, penuntutan, dan pemeriksaan di sidang pengadilan, yaitu perkara perusakan hutan harus didahulukan dari perkara lain untuk diajukan ke sidang pengadilan guna penyelesaian secepatnya. ${ }^{20}$ Perbuatan perusakan hutan dalam Undang-undang Nomor 18 Tahun 2013 meliputi dua kegiatan berikut:

a. Pembalakan liar, yaitu semua kegiatan pemanfaatan hasil hutan kayu secara tidak sah yang terorganisasi.

19 Tinjauan Tentang Putusan Terhadap Tindak Pidana Illegal Logging" <https/l:AT wibowo-2009-e-journal.uajy.ac.id> diakses tanggal 27 febuari 2019

20 Ahmad redi, Op.Cit, hlm. 239. 
b. Penggunaan kawasan hutan secara tidak sah adalah kegiatan terorganisasi yaitu penggunaan kawasan hutan secara tidak sah adalah kegiatan terorganisasi yang dilakukan di dalam kawasan hutan untuk perkwbunan atau pertambangan tanpa izin menteri kehutanan.

Perbuatan perusakan hutan secara terorganisasi merupakan kegiatan yang dilakukan oleh suatu kelompok yang terstruktur yang terdiri atas dua orang atau lebih, dan yang bertindak secara bersama-sama pada waktu tertentu dengan tujuan melakukan perusakan hutan. Kelompok terstruktur tidak termasuk kelompok masyarakat yang bertempat tinggal di dalam atau di sekitar masyarakat yang bertempat tinggal di dalam atau di sekitar kawasan hutan yang melakukan perladangan tradisional atau melakukan penebangan kayu di luar kawasan hutan konservasi dan hutan lindung untuk keperluan sendiri dan tidak untuk tujuan komersial.

Dalam rangka pemberantasan perusakan hutan, setiap orang dilarang:

a. Melakukan penebangan pohon dalam kawasan hutan yang tidak sesuai dengan izin pemanfaatan hutan.

b. Melakukan penebangan pohon dalam kawasan hutan tanpa memiliki izin yang dikeluarkan oleh pejabat yang berwenang.

1. Melakukan penebangan pohon dalam kawasan hutan secara tidak sah.

2. Memuat, membongkar, mengeluarkan, mengangkut, menguasai, atau memiliki hasil penebangan di kawasan hutan tanpa izin.

3. Mengangkut, menguasai, atau memiliki hasil hutan kayu yang tidak di lengkapi secara bersama surat keterangan sahnya hasil hutan.

4. Membawa alat-alat yang lazim digunakan untuk menebang, memotong, atau membelah pohon $\mathrm{di}$ dalam kawasan hutan tanpa izin pejabat yang berwenang.

5. Membawa alat-alat berat atau alatalat lain nya yang lazim atau patut diduga akan digunakan untuk mengangkut hasil hutan di dalam kawasan hutan tanpa izin pejabat yang berwenang.

6. Memanfaatkan hasil hutan kayu yang diduga berasal dari hasil pembalakan liar.

7. Mengedarkan kayu hasil pembalakan liar melalui darat, peraiaran, atau udara.

8. Menyeludupkan kayu yang berasal dari atau masuk ke wilayah Negara kesatuan republic Indonesia melalui sungai, darat, laut, atau udara.

9. Menerima, membeli, menjual, menerima tukar, menerima titipan, atau memiliki hasil hutan yang diketahui berasal dari pembalakan liar.

10. Membeli, memasarkan, atau mengolah hasil hutan kayu yang berasal dari kawasan hutan yang 
diambil atau dipungut secara tidak sah.

11. Menerima, menjual, menerima tukar, menerima titipan, menyimpan, dan atau memiliki hasil hutan kayu yang berasal dari kawasan hutan yang diambil atau dipungut secara tidak sah.

Setiap orang juga dilarang melakukan penyalahgunaan dokumen angkutan hasil hutan kayu yang di terbitkan oleh pejabat yang berwenang. Setiap orang yang melakukan pengangkutan kayu hasil hutan wajib memiliki dokumen yang merupakan surat keterangan sahnya hasil hutan sesuai dengan ketentuan peraturan perundang-undangan.

Hukuman terhadap kejahatan-kejahatan tersebut di atas dikenai sanksi pidana dan juga hukuman berupa paksaan pemerintah, uang paksa, dan pencabutan izin. Paksaan pemerintah tersebut adalah tindakan hukuman yang dilakukan oleh pemerintah agar perusahaan atau badan hukum melakukan pemulihan hutan akibat perbuatannya melakukan perusakan hutan karena tidak mematuhi ketentuan dalam peraturan perundang-undangan. Selanjutnya uang paksa adalah uang yang harus dibayarkan dalam jumlah tertentu oleh badan hukum atau korporasi yang melanggar ketentuan dalam peraturan perundang-undangan sebagai pengganti dari pelaksanaan saksi paksaan pemerintah. ${ }^{21}$

Selain pemidanaan terhadap pelaku kerusakan hutan, Undang-undang Nomor 18 Tahun 2013 juga memberlakukan pemidanaan terhadap pejabat yang melakukan kegiatan-kegiatan yang berdampak pada perusakan hutan menerbitkan izin pemanfaatan hasil hutan kayu dan penggunaan kawasan hutan di dalam kawasan hutan yang tidak sesuai dengan kewenangannya:

a. Menerbitkan izin pemanfaatan di dalam kawasan hutan dan izin penggunaan kawasan hutan yang tidak sesuai dengan ketentuan peraturan perundang-undagan.

b. Melindungi pelaku pembalakan liar dan penggunaan kawasan hutan secara tidak sah.

c. Ikut serta melakukan permufakatan untuk terjadinya pembalakan liar dan penggunaan kawasan hutan secara tidak sah.

d. Melakukan permufakatan untuk terjadinya pembalakan liar dan penggunaan kawasan hutan secara tidak sah.

e. Menerbitkan surat keterangan sahnya hasil hutan tanpa hak.

f. Dengan sengaja melakukan pembiaran dalam melaksanakan tugas.

g. Lalai dalam melaksanakan tugas.

\section{Kesimpulan}

Pihak ketiga sebagai pemilik alat berat berhak melakukan upaya perlawanan selaku pihak ketiga. Yang diatur dalam ketentuan Pasal 206, Pasal 227-228 R.Bg dan Pasal 195 ayat (6) HIR. Derden verzet dapat diajukan pemilik alat berat selama perkara yang dilawan belum mempunyai putusan yang berkekuatan hukum tetap. Keberatan atas penyitaan dan pengunaan upaya hukum perlawanan pihak ketiga untuk memperoleh kembali barang miliknya yang dirampas berdasarkan putusan yang menyangkut barang bukti tindak pidana yang dinilai cukup relevan. 
Hukuman kepada pelaku yang melakukan tindak pidana perambahan hutan sebagaimana diatur didalam ketentuan pidana Pasal 82 Undangundang Nomor 13 tahun 2013 Tentang Pencegahan Dan Pemberantasan Tindak Pidana Kehutanan memberikan sanksi dipidana dengan pidana penjara paling singkat 1 (satu) tahun dan paling lama 5 (lima) tahun serta pidana denda paling sedikit Rp.500.000.000.00 (lima ratus juta rupiah) dan paling banyak Rp.2.500.000.000.00 (dua miliar lima ratus juta rupiah). Pada Pasal 85 bahwa seorang perseorangan yang dengan sengaja membawa alatalat lainnya yang lazim atau patut diduga akan digunakan untuk mengangkut hasil hutan didalam kawasan hutan tanpa izin pejabat yang berwenang sebagimana dikmaksud dalam Pasal 12 huruf $\mathrm{g}$ dipidana dengan pidana penjara paling singkat 2 (dua) tahun dan dan paling lama 10 (sepuluh) tahun dan pidana denda paling sedikit $R p$ 2.000.000.000.00 (dua miliar) dan paling banyak $\mathrm{Rp}$ 10.000.000.000.00 (sepuluh miliar).

\section{DAFTAR PUSTAKA}

\section{A. Buku}

Daliyo J.B. Pengantar Hukum Indonesia. Jakarta: Prenhalindo, 2001.

Kansil C.S.T. Pokok-pokok Hukum Pidana. Jakarta: Pradnya Paramita, 2004.

Muchsin. Perlindungan dan Kepastian Hukum. Surakarta, 2004.

Mulhadi. Diktat Hukum Perusahaan Bentuk-bentuk Badan Usaha di Indonesia. Medan, 2016.

Muis abdul \& Mohammad Taufik. Hukum Kehutanan di Indonesia. Jakarta: PT. Bineka Cipta, 2011.

Redi Ahmad. Hukum Sumber Daya Alam Dalam Sektor Kehutanan. Jakarta Timur: Sinar Grafika, 2014.

Rochmanhadi. Alat-alat Berat dan Penggunaannya. Jakarta: Dunia Grafika Indonesia, 1992.

Suteki \& Galang Taufan. Metode Penelitian Hukum. Depok: PT Raja Grafindo Persada, 2018.

Setiono. Rule of low (Supermasi Hukum). Surakarta, 2004.

Soetjipto Rahardjo. Permasalahan Hukum di Indonesia. Bandung, 1983.

Sentosa Sembiring. Hukum Dagang. Bandung: PT Citra Aditya Bakti, 2001.

Salim. Hukum Kontrak Teori dan Teknik Penyusunan Kontrak. Jakarta: Sinar Grafika, 2014.
Wirjono Prodjodikoro. Hukum Acara Pidana di Indonesia. Bandung: Sumur Bandung.

\section{B. Internet}

Laksmi, "Penyidikan Terhadap Tindak Pidana Perambahan Kawasan Hutan Cagar Biosfer Giam Siak Kecil Oleh Kepolisian Resrot Bengkalis Berdasarkan Undang-Undang Nomor 18 Tahun 2013", lihat dalam: <https://www.dap laksmi, w edorita-...mahasiswa (jom) bidang ilmu hukum,2018-jom.unri,ac.id> diakses tanggal 27 febuari 2019.

L Iksan, S Abdullah, "Peranan Kebijakan Negara Terhadap Perlindungan Hutan Untuk Menekan Laju Deforestasi Taman Nasional Tesso Nilo", lihat dalam: <https/l: L Ikhsan, S Abdullahlegalitas-jurnal hukum,2017legalitas.Unbari.ac.id> diakes tanggal 27 febuari 2019.

S Abdulllah, "Kebijakan Hukum Pidana Dalam Menanggulangi Tindak Pidana Ileggal Logging Di Provinsi Jambi", lihat dalam: <https/l:S Abdullah-legalitas: jurnal hukum,2016legalitas.unbari.ac.id> diakses tanggal 27 febuari 2019.

Wibowo, "Tinjauan Tentang Putusan Terhadap Tindak Pidana Illegal Logging", lihat dalam: $<$ https/l:AT wibowo-2009-e-journal.uajy.ac.id> diakses tanggal 27 febuari 2019 . 


\section{Peraturan perundang-undangan}

Undang-Undang Dasar Negara Republik Indonesia Tahun 1945

Kitab Undang-Undang Hukum Perdata

Undang-Undang Hukum Acara Pidana

Undang-Undang Nomor 41 Tahun 1999 tentang Kehutanan.

Undang-Undang Nomor 32 Tahun 2009 tentang Perlindungan Dan Pengelolaan Lingkungan Hidup.
Undang-Undang Nomor 18 Tahun 2013 tentang Pencegahan Dan Pemberantasan Perusakan Hutan.

Undang-Undang Nomor 40 Tahun 2007 tentang Perseroan Terbatas

Undang-Undang Nomor 19 Tahun 2003 tentang Badan Usaha Milik Negara.

Undang-Undang Nomor 17 Tahun 2012 tentang Koperasi. 